\title{
Analysis of the thoracic and abdominal mobility in elderly through computer photogrammetry
}

\author{
Nayara Priscila Dantas de Oliveira', Silvana Alves Pereira', Maria do Socorro Luna Cruz', Luiz Eduardo Lima de Andrade', \\ Thaissa Hamana de Macedo Dantas', Grasiela Nascimento Correia', Diego de Sousa Dantas'
}

\begin{abstract}
Background: Computerized photogrammetry has become a promising aspect for respiratory analysis, being a technology of low cost, good reproducibility and accuracy, compatible with the Brazilian public health situation. Objectives: To verify the applicability of the computerized photogrammetry method for analysis of thoracoabdominal mobility in the elderly. Methods: This is a methodological study, performed with 16 elderly women from Santa Cruz, RN, Brazil. Morphofunctional evaluation of body mass, stature, body mass index and thoracoabdominal mobility were performed through the computerized photogrammetry, whose technique was based on the capture of images at the maximum ventilation moments (maximal inspiration and expiration followed by apnea) of the elderly. For the delimitation of the thoracic wall were used $20 \mathrm{~mm}$ diameter markers positioned at specific anatomical points, and the images were treated through the irregular quadrilaterals system in the AutoCAD 2007 Software. Results: Using computerized photogrammetry was possible to identify areas of compartments and sub-compartments of the thoracic wall with higher values at the inspiratory moment when compared to the expiratory moment, and with a greater contribution of the thoracic compartment in the pulmonary ventilation process of the elderly at the inspiratory moment. In addition, in the studied sample there was a higher prevalence of overweight elderly women (56\%). Computerized photogrammetry was sensitive to the nutritional status of these elderly women, presenting areas of the abdominal compartment and sub-compartments with values higher than those presented by the elderly women with low weight. Conclusions: Computerized photogrammetry proved to be an effective and reliable technique for the thoracoabdominal mobility analysis of elderly women.
\end{abstract}

Keywords: Respiratory Mechanics; Photogrammetry; Elderly.

\section{INTRODUCTION}

Population aging is a worldwide phenomenon that has demanded special attention from researchers, civil society and governments in view of the health needs of this population and spending in the health and social sector ${ }^{(1-3)}$. Brazil has one of the highest growth rates of the world's elderly population, and it is necessary to adopt public policies that promote better health and quality of life for the elderly ${ }^{(1,3)}$. The aging process is physiologically accompanied by changes observed in all systems of the organism ${ }^{(1)}$. The respiratory system is considered the system that ages faster because of its exposure to external factors ${ }^{(2)}$. Over the years there will be changes in the morphology of all structures involved in the breathing process, and chest wall modifications are the ones that most compromise the respiratory biomechanics of the elderly ${ }^{(4,5)}$. The changes that occur in the chest wall throughout the biological aging process culminate in the loss of the elasticity of the thorax and consequently in the senile lung resulting from calcification of the costal and sternal joints, flattening of the vertebrae and reduction of intervertebral discs ${ }^{(2,4,5)}$. Such alterations promote changes in posture and respiratory effort of the elderly, as well as reduce the capacity of chest expansion and decrease pulmonary complacency ${ }^{(6,7)}$.

The morphofunctional set formed by the surface and kinematics of the thoracic cavity and the abdomen presents an important relation with breathing and alveolar ventilation ${ }^{(8)}$. Thus, noninvasive monitoring, with emphasis on chest wall evaluation, has acquired relevance in physiological processes present in the most diverse age groups, including the elderly ${ }^{(9)}$. Several surface methods, ruled by different physical principles, have presented good reproducibility and accuracy in clinical practice, such as cirtometry and plethysmography by inductance ${ }^{(9)}$, magnetometry ${ }^{(10)}$ and computerized photogrammetry ${ }^{(11)}$. However, efforts still need to be made to provide technologies of low cost, good reproducibility and accuracy in pneumology capable of allowing an objective evaluation compatible with Brazilian public health, especially in 
geriatrics, which respiratory monitoring is still scarce and with high cost. In this sense, computerized photogrammetry has become a promising aspect for respiratory analysis, presenting low cost and good reproducibility ${ }^{(12)}$. This instrument has been used in the determination of the chest type and calculation of the diaphragmatic index ${ }^{(13,14)}$, in Charpy angle analysis ${ }^{(15)}$, in measurement of thoracoabdominal compartments ${ }^{(16)}$, as well as in prediction of the postural changes influence due to the aging process and respiratory dysfunctions ${ }^{(1)}$. Thus, the objective of the present study is to evaluate the applicability of the computerized photogrammetry method for analysis of thoracoabdominal mobility in the elderly.

\section{METHODS}

It is a pilot study, conducted between May and July 2013, with 16 elderly women practicing physical activity of the ACORDI (Body Activities Awakening the Elderly: Multidisciplinary Education in Search of a Citizen's Old Age) project of Santa Cruz (RN), Brazil, approved by the Research Ethics Committee of the Universidade Federal do Rio Grande do Norte (UFRN) with protocol number 262.696. The study included women with 60 years or older, who were in the elderly group for at least one year and practiced physical activities at least twice a week, and who consented to participate in the study signing the Informed Consent Form. The elderly who presented severe thoracic deformities and/or who underwent recent thoracic surgery, as well as underwent medical treatment for respiratory diseases were excluded from the study. Initially, it was used a structured questionnaire, consisting of personal data, current and past medical history (respiratory and/or cardiovascular diseases), current respiratory symptoms (dyspnea, cough, expectoration, among others) and elderly lifestyles (smoking, alcoholism). It was performed a morphofunctional evaluation of the following variables: body mass (BM), height, body mass index (BMI), and thoracoabdominal mobility. The BM was measured by the electronic balance Welmy W200/100A (Welmy Balanças, Santa Bárbara D'Oeste - SP, Brazil) with precision of $100 \mathrm{~g}$. The procedure was performed with the elderly woman barefoot, wearing light clothing (top and knit trousers). The stature was measured by a stadiometer, with the elderly in an orthostatic position and barefoot, at the end of maximum inspiration ${ }^{(17)}$. The BMI was calculated by BM and the square of height $\left(\mathrm{kg} / \mathrm{m}^{2}\right)$ and classified in low weight, eutrophic and overweight ${ }^{(18)}$. The thoracoabdominal mobility was evaluated through computerized photogrammetry. For the collection of the images was used a digital camera Casio Exilim Exz75 (Casio Computer Co., Ltd. Shibuya, Tóquio, Japan), 7.2 mega pixels, positioned at a distance of 2.5 meters from the participant in a tripod with an height of 1 meter, as recommended by Junior et al. ${ }^{(19)}$. A symmetograph was used as background of the images, which worked as a calibrator of the photos for the evaluator. At the moment of the photographs, the elderly woman remained standing in the neutral position, with an angle of 30 a and a distance of two centimeters between her heels, in addition to wearing clothes that allowed maximum exposure of the thoracic and abdominal region ${ }^{(19)}$, as illustrated in Figure.

The delimitation of the chest wall of each participant was performed using spherical markers with $20 \mathrm{~mm}$ in diameter and the flat face in contact with the skin of the elderly, distributed in the following anatomical points predetermined in the BAMER method, as shown in Figure 2: (1) acromioclavicular joints; (2) xiphoid appendix; (2a) lateral aspect of the xiphoid appendix; (3) costal arch of the twelfth rib; (4a) level of the umbilical scar, projected laterally; e (5) anterior-superior iliac spines $^{(12)}$.

Each participant was instructed to perform respiratory maneuvers starting from residual volume (RV) to total lung capacity (TLC), followed by apnea moments of three seconds after maximal inspiration and expiration. The photographs were captured after this instruction and for each condition an image was collected for left lateral view and one for right lateral view. The images collected were analyzed in the AutoCAD Map 3D 2007 (https://knowledge.autodesk.com/ support/autocad-map-3d) free trial software, in which the extension of the thoracic cavity was delimited, superiorly, from the acromioclavicular joint, and inferiorly, to the anterior superior iliac spine; and divided in thoracic (TX) and abdominal (AB) compartments at the costal arch of the twelfth rib. These compartments were again divided allowing the origin of the upper (UT) and lower (LT) thoracic subcomponents at the level of lateral projection of the xiphoid appendix and the upper (US) and lower (LS) subcomponents at the level of lateral projection of the umbilical scar ${ }^{(12)}$. The measure of respiratory expansion was then expressed by the lateral area of each compartment in $\mathrm{cm}^{2}$, and calculated by the irregular quadrilaterals model ${ }^{(12)}$. The obtained data were

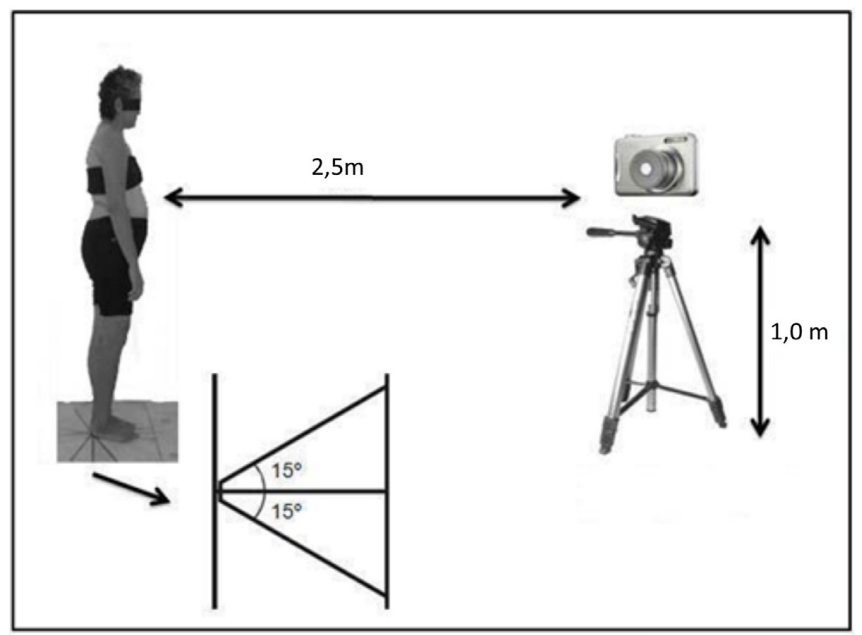

Figure 1. Special conditions for the collection of the images in Computerized Photogrammetry. 
submitted to statistical treatment in the Software Package for the Social Sciences (SPSS), IBM Modeler Administration Console version 20.0 (Chicago, SPSS Inc.). Compartment and sub-compartment data were expressed as means and standard deviation, as well as percentiles. The correlation between the coefficients of expansion of the different compartments and sub-compartments was calculated by Pearson's correlation and the areas for the different measures at the inspiratory and expiratory moments were compared between the three classification groups of BMI using ANOVA, and in both cases, it was considered significant when $p<0.05$ and it was considered as a null hypothesis when there was no difference between the expandability of the different compartments and sub-compartments.

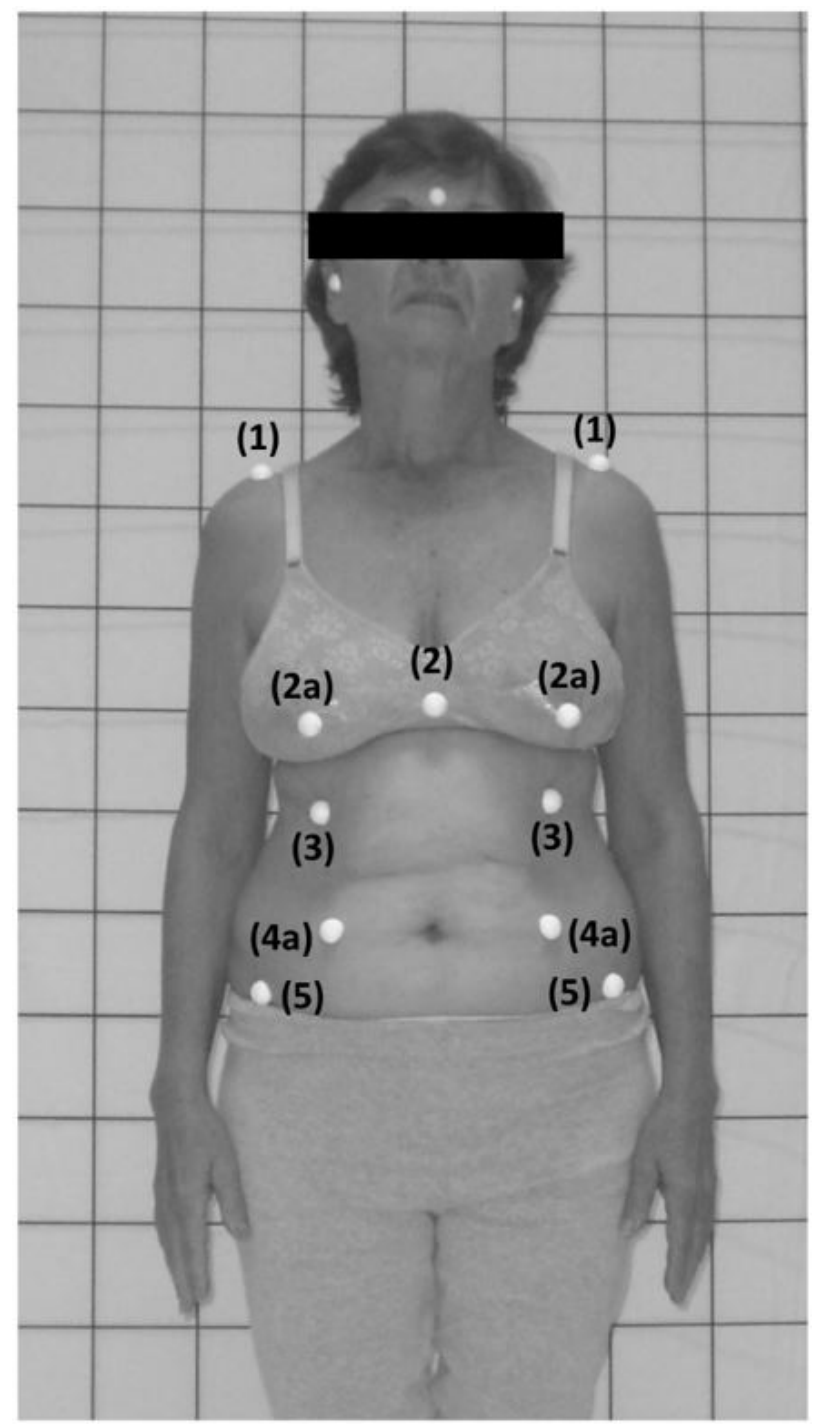

Figure 2. Distribution of surface spherical markers. (1) acromioclavicular joints; (2) xiphoid appendix; (2a) lateral aspect of the xiphoid appendix; (3) costal arch of the twelfth rib; (4a) level of the umbilical scar, projected laterally; e (5) anterior-superior iliac spines.

\section{RESULTS}

The sample was composed of 16 elderly women with a mean age of $68 \pm 1.46$ years, BMI of $60 \pm 3.7 \mathrm{~kg}$, height of $1.52 \pm 0.002 \mathrm{~m}$ and mean BMI of $27.56 \pm 0.95 \mathrm{~kg} / \mathrm{m}^{2}$. In relation to the frequency of distribution and stratification of BMI, a prevalence of overweight elderly women was found, approximately $56 \%(n=9)$, followed by eutrophic elderly with $37.5 \%(n=6)$ and only one elderly with low weight (6.3\%). For each participant, four photographic records were made, two for each lateral view, corresponding to the moments of inspiration and maximum expiration, totaling 64 photographic records. In each image, the thoracic wall (TW) was divided into two compartments and four sub-compartments (Figure 3), resulting in the final calculation of 448 areas.

Table 1 shows the mean values and the distribution in percentiles of the results of the areas obtained in each compartment and sub-compartments from the division of the TW, showing that for all compartments and sub-compartments the values of the areas found were superior in the maneuvers of maximum inspiration when compared to maximum expiration.

To evaluate the thoracoabdominal expansibility of elderly was used the expansibility coefficient, obtained by the difference between the area found at the maximum inspiration moment and the area of the expiration moment for each compartment or sub-compartment. From these coefficients, it was investigated the correlation between the measurements of compartments and sub-compartment areas, being a positive correlation between LT with TX and TW, UA with AB and TW, as well as between LA with AB. The UT sub-compartment did not show statistically significant correlation with TX and TW, as can be seen in Table 2 .

When analyzing the behavior of compartments and sub-compartment areas in relation to BMI classification,

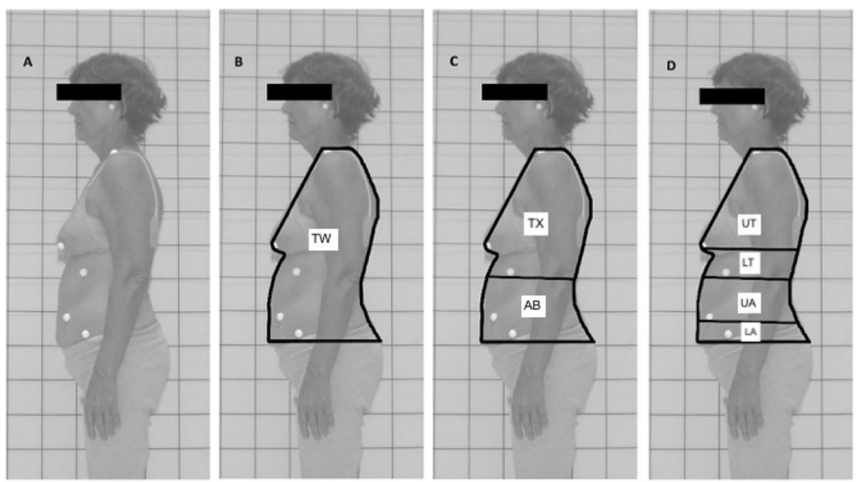

Figure 3. Representation of thoracic and abdominal compartments. a. Distribution of surface markers; b. Demarcation of the thoracic wall (TW); c. Demarcation of TW divided into thoracic (TX) and abdominal (AB) compartments at the level of the costal arch of the tenth rib. d. The TX subdivided at the level of the xiphoid appendix in upper thoracic (UT) and lower thoracic (LT); AB divided into upper abdominal (UA) and lower abdominal (LA) compartment at the height of the umbilical scar. 
Table 1. Inspiratory and expiratory values in $\mathrm{cm}^{2}$ for areas of the chest wall in each compartment and sub-compartment by the computerized phot-grammetry method.

\begin{tabular}{|c|c|c|c|c|c|c|}
\hline \multirow{2}{*}{ Measure } & \multirow{2}{*}{ Moment } & \multirow{2}{*}{ Mean } & \multirow{2}{*}{ SD } & \multicolumn{3}{|c|}{ Percentile } \\
\hline & & & & $25 \%$ & $50 \%$ & $75 \%$ \\
\hline \multicolumn{7}{|c|}{ Compartments } \\
\hline \multirow[t]{2}{*}{ TX } & Insp. & 1981.012 & 166.318 & 1879.049 & 1959.107 & 2042.823 \\
\hline & Exp. & 1933.427 & 213.483 & 1795.032 & 1938.036 & 2035.934 \\
\hline \multirow[t]{2}{*}{$A B$} & Insp. & 1679.068 & 434.00 & 1293.449 & 1728.194 & 2057.544 \\
\hline & Exp. & 1507.206 & 419.079 & 1193.337 & 1573.130 & 1862.405 \\
\hline \multirow[t]{2}{*}{ TW } & Insp. & 3660.089 & 540.974 & 3149.387 & 3719.947 & 4070.356 \\
\hline & Exp. & 3440.633 & 577.475 & 3041.636 & 3436.413 & 3917.701 \\
\hline \multicolumn{7}{|c|}{ Sub-compartments } \\
\hline \multirow[t]{2}{*}{ UT } & Insp. & 1390.158 & 184.194 & 1235.079 & 1390.486 & 1545.031 \\
\hline & Exp. & 1436.655 & 193.093 & 1319.960 & 1406.456 & 1518.567 \\
\hline \multirow[t]{2}{*}{ LT } & Insp. & 590.854 & 214.559 & 434.989 & 579.526 & 673.370 \\
\hline & Exp. & 496.772 & 198.786 & 357.531 & 502.125 & 599.327 \\
\hline \multirow[t]{2}{*}{ UA } & Insp. & 1065.236 & 392.789 & 767.054 & 1027.126 & 1369.191 \\
\hline & Exp. & 935.363 & 377.203 & 696.050 & 897.894 & 1266.921 \\
\hline \multirow[t]{2}{*}{ LA } & Insp. & 615.705 & 147.179 & 469.314 & 597.001 & 736.417 \\
\hline & Exp. & 571.843 & 142.915 & 426.977 & 574.837 & 697.326 \\
\hline
\end{tabular}

Note: SD: standard deviation; TX: thoracic compartment; AB: abdominal compartment; TW: thoracic wall; UT: upper thoracic sub-compartment; LT: lower thoracic sub-compartment; UA: upper abdominal sub-compartment; LA: lower abdominal sub-compartment.

Table 2. Correlation between the expansibility coefficients of compartments and sub-compartments by means of Computerized Photogrammetry.

\begin{tabular}{|c|c|c|c|c|c|c|c|}
\hline & UT & LT & TX & UA & LA & $A B$ & TW \\
\hline UT & 1 & $-0.518^{*}$ & 0.481 & -0.297 & -0.297 & -0.401 & 0.076 \\
\hline LT & $-0.518 *$ & 1 & $0.501 *$ & $0.530 *$ & -0.257 & 0.260 & $0.584 *$ \\
\hline $\mathrm{TX}$ & 0.481 & $0.501 *$ & 1 & 0.243 & $-0.564 *$ & -0.140 & $0.675 * *$ \\
\hline UA & -0.297 & $0.530 *$ & 0.243 & 1 & -0.088 & $0.773 * *$ & $0.765^{* *}$ \\
\hline LA & -0.297 & -0.257 & $-0.564 *$ & -0.88 & 1 & $0.555^{*}$ & -0.026 \\
\hline$A B$ & -0.401 & 0.260 & -.0140 & $0.773 * *$ & $0.555^{*}$ & 1 & $0.636 * *$ \\
\hline TW & 0.076 & $0.584 *$ & $0.675 * *$ & $0.765^{* *}$ & -0.026 & $0.636 * *$ & 1 \\
\hline
\end{tabular}

Note: Difference between inspiration and expiration of the: UT: upper thoracic sub-compartment; LT: lower thoracic sub-compartment; TX: total thoracic compartment; UA: upper abdominal sub-compartment; LA: lower abdominal sub-compartment; AB: total abdominal compartment; TW: thoracic wall; *: $p<0.05 ;{ }^{* *}: \mathrm{p}<0.01$.

statistically significant differences were observed between the low weight (LW), eutrophic (EU) and overweight (OW) groups to the TW, AB compartment and UA and LA sub-compartments, as shown in Table 3.

\section{DISCUSSION}

The results of the present study show that in all compartments and sub-compartments, originating from the TW division, the areas calculated at the inspiratory moment were quantitatively larger than those found at the expiratory moment, and areas of the thoracic compartment (TX) with values greater than the areas of the abdominal compartment $(A B)$. The analysis of the mechanics and kinematics of the thoracoabdominal structures during the respiratory movements is directly related to the displaced lung volumes during the inspiration and expiration processes ${ }^{(23)}$. The TW consists of incompressible tissues, which leads to displacement of thoracic and abdominal surfaces when occurs any changes in lung volume ${ }^{(15)}$. Thus, the mobility of such structures allows the determination of non-invasive volumetric estimates, and there is no need for the use of airway connection devices. The present study corroborated with this based on the results obtained with the application of computerized photogrammetry to analyze the TW mobility of elderly during respiratory events. A similar result to the study of Ripka, Ulbricht and Gewehr ${ }^{(11)}$, which used a similar 
Table 3. Repercussions of BMI in mean area values obtained in different compartments and sub-compartments.

\begin{tabular}{|c|c|c|c|c|c|}
\hline \multirow{2}{*}{ Measure } & \multirow{2}{*}{ Moment } & \multicolumn{3}{|c|}{ BMI } & \multirow{2}{*}{ p*Value } \\
\hline & & $\mathbf{L W}^{* *}$ & EU & ow & \\
\hline \multicolumn{6}{|c|}{ Compartments } \\
\hline \multirow[t]{2}{*}{$\mathrm{TX}$} & Insp. & 1796.14 & $1929.53 \pm 50.91$ & $2052.37 \pm 52.02$ & 0.110 \\
\hline & Exp. & 1794.29 & $1868.94 \pm 39.65$ & $2032.78 \pm 60.71$ & 0.045 \\
\hline \multirow[t]{2}{*}{$A B$} & Insp. & 1237.29 & $1388.67 \pm 121.67$ & $1959.28 \pm 88.26$ & 0.008 \\
\hline & Exp. & 1132.63 & $1220.41 \pm 107.61$ & $1785.69 \pm 81.51$ & 0.035 \\
\hline \multirow[t]{2}{*}{ TW } & Insp. & 3033.43 & $3318.20 \pm 153.87$ & $4011.65 \pm 93.34$ & 0.014 \\
\hline & Exp. & 2926.92 & $3089.35 \pm 141.00$ & $3818.47 \pm 99.24$ & 0.003 \\
\hline \multicolumn{6}{|c|}{ Sub-compartments } \\
\hline \multirow[t]{2}{*}{ UT } & Insp. & 1229.86 & $1350.12 \pm 50.91$ & $1449.68 \pm 64.80$ & 0.162 \\
\hline & Exp. & 1335.51 & $1406.49 \pm 26.73$ & $1498.88 \pm 70.10$ & 0.214 \\
\hline \multirow[t]{2}{*}{ LT } & Insp. & 566.27 & $579.41 \pm 58.64$ & $602.69 \pm 90.05$ & 0.948 \\
\hline & Exp. & 458.79 & $462.44 \pm 39.46$ & $533.90 \pm 84.17$ & 0.698 \\
\hline \multirow[t]{2}{*}{ UA } & Insp. & 815.77 & $866.88 \pm 132.79$ & $1260.04 \pm 111.22$ & 0.035 \\
\hline & Exp. & 729.15 & $732.58 \pm 112.72$ & $1135.07 \pm 106.08$ & 0.035 \\
\hline \multirow[t]{2}{*}{ LA } & Insp. & 451.52 & $526.80 \pm 46.66$ & $699.25 \pm 37.57$ & 0.029 \\
\hline & Exp. & 403.47 & $487.83 \pm 51.71$ & $650.62 \pm 34.55$ & 0.035 \\
\hline
\end{tabular}

Note: BMI: Body Mass Index; LW: Low weight; EU: Eutrophic; OW: Overweight; TX: thoracic compartment; AB: abdominal compartment; TW: Thoracic wall; UT: upper thoracic sub-compartment; LT: lower thoracic sub-compartment; UA: upper abdominal sub-compartment; Al: lower abdominal sub-compartment; *Calculated by ANOVA; **The values for the LW group show the absolute values obtained.

methodology, found that the mean values of compartments and sub-compartment areas were higher in the inspiratory moment, as well as for the thoracic compartments, with a mean of $624.05 \pm 166.51 \mathrm{~cm}^{2}$ for subjects of both sexes with 14 to 17 years. The difference observed in relation to mean and standard deviation values between the two studies is justified by the significant difference between the populations studied regarding age, sex, height and $\mathrm{BM}$, indicating the possibility of detection of areas mean values for each age group.

The results of the present study can also be compared to the findings of Ricieri and Filho ${ }^{(12)}$, when they proposed to evaluate the respiratory mechanics of healthy adults in pre and post physical exercise situations through computerized photogrammetry, showing that this method was able to evaluate two-dimensional thoracoabdominal respiratory movement. Another study also developed by Ricieri and Filho $^{(16)}$ with asthmatic children showed the effectiveness of the photogrammetric method in differentiating the variations of the thoracoabdominal contour during the execution of isovolume maneuvers, however, this work differs from the present study because there is an adaptation of the geometric model to the lying position of the evaluated one, as well as the use of respiratory maneuvers of abdominal and thoracic isovolume, allowing the analysis of TW movement just in respiration.

Computerized photogrammetry applies the cystometric concepts associated with plethysmography points in order to quantitatively assess thoracoabdominal mobility, and it is possible to compare the results of both methods ${ }^{(11)}$. Studies that use the inductance plethysmography method ${ }^{(25,26)}$ showed that the elderly present a greater thoracoabdominal asynchrony when compared to young adults, which may be due to the morphofunctional changes that occur with the senescence process ${ }^{(25)}$. During the respiratory movements, the chest and abdomen move independently, and the displacement of the thoracoabdominal surface is directly related to the variation of lung volume ${ }^{(16)}$. In this way, the subdivisions of TW performed in the study allowed the detailed analysis of the contribution of each area to the total lung volume during respiratory maneuvers ${ }^{(27)}$, there is a correlation between the sub-compartment and the compartment of which it is part, as well as with TW. This event was verified in all sub-compartments, except for UT, which had no correlation with TX, nor with TW. However, the results evidenced a significantly greater contribution of the TX compartment to the total volume when compared to the $A B$ compartment. The study of Loula ${ }^{(26)}$ with young subjects of both sexes present results similar to those found in this study, showing a greater participation of the thorax to the pulmonary volume during the maneuvers of maximum ventilation. The negative values of the coefficients of expansion exhibited in the study show the occurrence of phase inversion, corroborating with Loula(26), which exposes an inversely proportional relationship between the TW total area and the sub-compartment area, 
so that while the TW area or compartment increases, the sub-compartment area decreases, thus contributing negatively to the total value. Changes in BMI can affect the mobility of the chest and abdomen, interfering with the lung function of subjects even when their lungs are healthy. Increased BMI promotes a reduction in lung and chest wall compliance, resulting in a decrease in the extrapulmonary structures distensibility, due to the adipose tissue in abdominal and thoracic regions ${ }^{(28)}$. Thus, computerized photogrammetry would be an instrument capable of quantitatively identifying such changes in the respiratory mechanics of overweight or obese subjects. However, no studies are found in the literature that use computerized photogrammetry for this purpose.

The present study shows that the elderly of the sample classified as overweight presented areas of the TW compartments and sub-compartments greater in relation to the areas calculated for the eutrophic and low weight participants, being a statistically significant difference for the $A B$ compartment and $A U$ and $L A$ sub-compartments in the inspiratory and expiratory moments. This fact can be justified by the accumulation of adipose tissue in the abdominal region and is not related to a possible increase in the distensibility of such extrapulmonary structures in respiratory movements ${ }^{(28)}$. Therefore, computerized photogrammetry was an instrument capable of predicting, through non-invasive analysis of the thoracoabdominal surface, the repercussions of BMI on the respiratory mechanics of the elderly women who composed the sample. The number composing the study sample is a limiting factor, mainly in relation to the repercussions of BMI on the mobility of the thoracoabdominal structures of the evaluated elderly women, and it is necessary to carry out new studies with more numerous samples that can evidence the effectiveness of the computerized photogrammetry for such analysis. The findings corroborate other evidence available in the literature that report computerized photogrammetry as a low-cost technique with good precision in the respiratory area, presenting easy photointerpretation and the ability to archive the records, which justifies its increasing use ${ }^{(29,30)}$. Some limitations of the method may influence its accuracy. In the sample studied, some difficulties were mainly related to the use of appropriate clothing for the upper chest region, considering that the breast volume may make it difficult to visualize the surface boundaries used to delimit the TW in the photointerpretation phase, and may interfere, especially, in the determination of the thoracic compartments areas. In addition, the understanding of respiratory maneuvers and their satisfactory execution is of paramount importance for the method reliability.

\section{CONCLUSION}

The use of computerized photogrammetry to analyze the thoracoabdominal mobility of elderly women allowed to establish in a clear and simple way the evidences regarding the synergy and kinematics of the chest wall regions during the respiratory movements, as well as it was sensitive in relation to the nutritional status of the elderly women. Thus, it is possible to show the reliability of the method for the analysis of the respiratory mechanics of the elderly, consisting of another resource for monitoring the respiratory physiological alterations of this population. So, the study presents initial contributions for the use of this method in the respiratory semiology of elderly people, showing its quality for quantitative analyzes.

\section{AUTHORS CONTRIBUTIONS}

NPDO, SAP, THMD and DSD: study design; NPDO, MSLC and LELA: data collection; NPDO, DSD, LELA and GNC: statistical analysis; NPDO, SAP, DSD, MSLC, THMD and GNC: critical intellectual review of the manuscript. All authors read and approved the final manuscript.

\section{CONFLICT OF INTERESTS}

The authors declare that there was no conflict of interests.

\section{REFERENCES}

1. Pettenon R, Milano D, Bittencourt DC, Schneider RH. Adaptação funcional do aparelho respiratório e da postura no idoso. Rev Bras Ciênc Envelhec Hum. 2008;5(2):64-77.

2. Ruivo S, Viana P, Martins C, Baeta C. Efeito do envelhecimento cronológico na função pulmonar. Comparação da função respiratória entre adultos e idosos saudáveis. Rev Port Pneumol. 2009;15(4):629-53.

3. Brasil. Ministério da Saúde. Secretaria de Atenção à Saúde. Departamento de Ações Programáticas e Estratégicas. Área Técnica Saúde do Idoso. Atenção à saúde da pessoa idosa e envelhecimento. Brasília (DF): Ministério da Saúde; 2010.

4. Pascotini FS, Fedosse E, Ramos MC, Ribeiro VV, Trevisan ME. Força muscular respiratória, função pulmonar e expansibilidade toracoabdominal em idosos e sua relação com o estado nutricional. Fisioter Pesqui. 2016;23(4):416-22.

5. Farrareze M, Piccoli JCJ, Souza RM. Gordura corporal e função pulmonar: um estudo em idosas de Novo Hamburgo, RS, Brasil. Rev Univ Educ Fis Deport. 2014;7(7):69-75.

6. Fechine BRA, Trompieri N. O processo de envelhecimento: as principais alterações que acontecem com o idoso com o passar dos anos. Rev Cient Int. 2012; 20(1):106-12.

7. Britto RR, Zampa CC, Oliveira TA, Prado LF, Parreira VF. Effects of the aging process on respiratory function. Gerontology. 2009;55(5):505-10.

8. Petternon R, Milano D, Bittencourt DC, Schneider RH. Adaptação funcional do aparelho respiratório e da postura do idoso. Rev Bras Ciênc Envelhec Hum. 2008,5(2):64-77.

9. Caldeira VS, Starling CCD, Britto RR, Martins JA, Sampaio RF, Parreira VF. Precisão e acurácia da cirtometria em adultos saudáveis. J Bras Pneumol. 2007;33(5):519-26.

10. Almeida VP, Guimarães FS, Moço VJR, Menezes SLS, Mafort TT, Lopes AJ. Correlação entre função pulmonar, postura e composição corporal em pacientes com asma. Rev Port Pneumol. 2013;19(5):204-10.

11. Ripka WL, Ulbricht L, Gewehr PM. Application of a photogrammetric kinematic model for prediction of lung volumes in adolescents: a pilot study. Biomed Eng Online. 2014;13(1):21.

12. Ricieri DV, Filho NAR. Impacto de fatores externos sobre a mecânica respiratória avaliada por um modelo fotogramétrico específico: biofotogrametria. J Bras Pneumol. 2008;34(9):702-6.

13. Ricieri DV, Costa JR, Filho NAR. Impacto da asma sobre a postura corporal de crianças entre 8 e 14 anos. Acta Fisiátr. 2008;15(4):214-9.

14. Godoy VAH, Lautenschlaeger J, Deloroso FT, Guedes CV, Alves MC. Avaliação do padrão respiratório com base no índice diafragmático obtido pela biofotogrametria computadorizada. Fisioter Bras. 2009;10(2):99-105. 
15. Baraúna MA, Deloroso MGB. Método fotogramétrico de rastreamento do ângulo de Charpy em crianças asmáticas e não asmáticas. Fisioter Bras. 2000;1(2):75-84.

16. Ricieri DV, Rosário Filho NA. Efetividade de um modelo fotogramétrico para a análise da mecânica respiratória toracoabdominal na avaliação de manobras de isovolume em crianças. J Bras Pneumol. 2009;35(2):144-50.

17. Matsudo V. Testes em ciências do esporte.7ạ ed. São Caetano do Sul: Celafiscs; 2005.

18. Tavares EL, Santos DM, Ferreira AA, Menezes MFG. Nutritional assessment for the elderly: modern challenges. Rev Bras Geriatr Gerontol. 2015;18(3):643-50.

19. Silva Junior JR. Avaliação biomecânica cinemétrica computadorizada por fotografia digital como recurso na análise postural. In: Vasconcelos DA, Barbosa e Silva MS, Silva Junior JR. 1a ed. Campina Grande: EDUEPB; 2008. p. 95-126.

20. Buzzachera CF, Krause MP, Elsangedy HM, Hallage T, Granato P, Krinski $K$ et al. Prevalência de sobrepeso e obesidade geral e central em mulheres idosas da cidade de Curitiba, Paraná. Rev Nutr. 2008;21(5):525-33.

21. Boscatto EC, Duarte MFS, Coqueiro RS, Barbosa AR. Nutritional status in the oldest elderly and associated factors. Rev Assoc Med Bras. 2013;59(1):40-7.

22. Cavalcanti CL, Gonçalves MCR, Asciutti LSR, Cavalcanti AL. Prevalência de doenças crônicas e estado nutricional em um grupo de idosos brasileiros. Rev salud pública. 2009;11(6):865-77.
23. Ricieri DV, Filho NAR, Costa JR. Razão entre diâmetros torácicos para detecção de hiperinsuflação estática em crianças pela biofotogrametria. J Pediatr. 2008;84(5):410-5.

24. Parreira VF, Bueno CJ, França DC, Vieira DSR, Pereira DR, Brito RR. Padrão respiratório e movimento toracoabdominal em indivíduos saudáveis: influência da idade e do sexo. Rev Bras Fisioter. 2010;14(5):411-6.

25. Franco SS, Bardi PN, Grinberg M, Feltrin MIZ. Estudo do padrão respiratório e movimento toracoabdominal em valvopatia mitral. Arq Bras Cardiol. 2012;99(5):1049-55.

26. Loula CMA. Análise de volumes parciais do tronco durante respiração por videogrametria [dissertação]. Campinas: Universidade Estadual de Campinas; Faculdade de Educação Física; 2005.

27. Rasslan Z, Saad Junior R, Stirbulov R, Fabbri RMA, Lima CAC. Avaliação da função pulmonar na obesidade graus I e II. J Bras Pneumol. 2004;30(6):508-14.

28. Souza JA, Pasinato F, Basso D, Corrêa ECR, Silva AMT. Biofotogrametria confiabilidade das medidas do protocolo do software para avaliação postural (SAPO). Rev Bras Cineantropom Desempenho Hum. 2011;13(4):299-305.

29. Lopes FB, Merey LSF, Santos MLM, Barbosa SRM. Análise comparativa do ângulo de Charpy em crianças asmáticas e não asmáticas por meio da biofotogrametria computadorizada. Fisioter Bras. 2012;13(4):293-8. 